\title{
Kant’s Respect for the Law and Habermas's Redemption as a Source of Freedom?
}

\begin{abstract}
Domenic Garcia
Newcastle University

As the title of this paper suggests, I intend to draw attention to what, in my opinion, lies at the core of the shared notion in both Kant and Habermas. This will be the concern of the first part of my paper. My focus will then shift, in the second part, to Habermas's views on freedom. In due time, however, as the provocative question mark in the title suggests, the notion of freedom becomes questionable. I will conclude by examining Frankfurt's notion of coercion in order to show that Habermas's notion of freedom is not only questionable but can, at times, be coercive. Throughout this paper, the reader shall be encouraged to see and possibly appreciate that there is a degree of similarity between the two thinkers. Shall the reader be hard put to gauge this similarity or shall the reader promptly appreciate it and take it into consideration? I will argue — and demonstrate—-that a certain amount of similarity can readily be drawn between the two. I will leave it up to the reader to decide whether this similarity is a forced similarity or whether this is a similarity that one perceives at a first glance and thus ought to consider. This paper could better be appreciated if the reader has reasonable knowledge of the Hegelian critique of Kant's Categorical Imperative.
\end{abstract}

Keywords: validity claims, discourse ethics, quasi-transcendental, freedom, coercion

\section{Habermas’s Affinities with Kantian Ethics}

\subsection{Kant and Habermas-Some Shared Notions}

When setting out to discuss Habermas's eclectic and brilliant works, it is important to find an inroad, and I think it would be reasonable to adopt the notion of discourse ethics - which embeds itself in his ideal speech situation—as an appropriate inroad. This would, in turn, lead us to other inroads, namely his validity claims, the normative reality, in other words, of our "social life-world of shared values and norms, roles, and rules that an act can 'fit' or 'misfit' and that are either 'right'—legitimate, justifiable—or 'wrong'” (McCarthy 1989, 280).

Accordingly, a speaker who utters a sentence is, of necessity, making validity claims. If I say "one should not steal," I would be making a validity claim or "claim to be right" referring, therefore, to what is legitimate or justifiable. Habermas believes that citizens obey laws not because they are afraid of sanctions but because they feel that they should respect laws. They believe that it is right to obey laws: "the speaker must choose an utterance that is right [richtig] so that the hearer can accept the utterance and both speaker and hearer can agree with one another in the utterance with respect to a recognized normative background" (Habermas 1979, 3). This particular law has, by implication, a moral legitimacy for the person in question as well as society as a whole.

Domenic Garcia, Ph.D. candidate, teacher of Philosophy, Department of Philosophy, Giovanni Curmi Higher Secondary School, Malta; main research fields: Philosophy of Language, Ethics, and Political Theory. Email: 1830conc@gmail.com. 
Should, however, these validity claims break down, communication can (still) continue providing that the basis of the misunderstanding is cleared up during the process of interaction: Habermas holds that while validity claims can be redeemed within the context of interaction, claims of "truth and rightness are such that their vindication may call for 'stepping out' of a given action context and 'into' a discursive situation” (McCarthy 1989, 289).

He distinguishes, in fact, between two different forms of communicative action: interaction and discourse. Validity claims are necessarily raised in every speech act but, for Habermas, their force is only viewed as theoretical and openly thematized in discourse (McCarthy 1989, 291). McCarthy (1989) further explains that discourse is characterized by a certain break with the normal context of interaction. One should speak of discourse "only when the meaning of the problematic validity claim conceptually forces participants to suppose that a rationally motivated agreement could in principle be achieved, whereby the phrase 'in principle' expresses the idealizing proviso: if only the argumentation could be conducted openly and continued long enough” (Habermas 1986, 42). This brings us another inroad into Habermas's work: its affinity with the Kantian Morality. Habermas may be shaping his notion of validity claims in the mould of the Kantian morality which states that if you will the end, then you will the means to this end. This means that as soon as you are engaged in discourse, you have to accept the ideal aim of discourse (Finlayson 1989, 5). To better understand this similarity, it is worth reflecting on the Kantian understanding of respect for the law and comparing it with the Habermasian notion of redemption of validity claims.

As such, one way in which Habermas's position can be understood vis-à-vis Kantian morality is to consider his revival of social normativity, an endeavour which he undertakes through communicative ethics and which can be identified as a "non-idealist Kantian response to the Hegelian critiques of transcendental moralities" (Rose 2007, 147). Habermas's work points in the direction of "transformed transcendental philosophy," a phrase which was subsequently modified into "rational reconstruction of universal competences” (McCarthy 1989, 278). As in Kant’s transcendental philosophy, the idea of universal pragmatics aims at disclosing conditions of possibility with the possibility shifting from the possibility of experiencing objects to the possibility of reaching understanding in ordinary language communication (McCarthy 1989, 278-79).

Habermas moves from the strong a priori assumptions of the Kantian form-the transcendental deduction - to a "relativized a priori" which is, in other words, one that recognizes the empirical boundary conditions of universal structures as well the structural interconnection of experience and action (McCarthy 1989, 279). This shows that, on the one hand, Kant draws a sharp distinction between transcendental and empirical analysis while, on the other, the "rational reconstruction" perceived by Habermas is dependent on a posteriori knowledge (Habermas 1979, 24-5). Habermas is of the opinion, therefore, that "the rule-consciousness of competent speakers is for them and a priori knowledge” (Habermas 1979, 24), but he also maintains, at the same time, that the reconstruction of this knowledge requires that inquiry be made of empirical speakers- the linguistic procures a posteriori knowledge (Habermas 1979, 25).

One cannot rely on reflection or on one's own linguistic intuitions to evaluate competing reconstructive proposals. Habermas believed, in contrast to Kant, that the individual cannot be a transcendental ego equipped with a priori forms of intuition and categories of understanding (McCarthy 1989, 295). According to McCarthy (1989), Habermas's individual is an interacting individual and his world of experiences ought to be envisaged as the result of linguistic communication. 


\subsection{Habermas and the Transcendental}

Habermas, however, still believes that the notion of the "transcendental" can be retained, albeit in a reduced sense (McCarthy 1989, 296). He intentionally uses the phrase "reduced sense” in order to convey the idea that his notion no longer carries the claims associated with transcendental deduction. He believes that rational experience is organized in a network of categories and, insofar as we discover the same system of fundamental concepts behind every experience, we can regard them as “quasi-transcendental” (McCarthy 1989, 296). At the same time, however, he does not agree with the idea that this entails an abandonment of the concept of "constitution." For him, the "universal-pragmatic analysis" applied to these concepts can be regarded as a transformed constitution theory of experience (Habermas 1979, 21).

Now this notion of "quasi-transcendental” or "rational reconstruction” involves another notion-rational will. For Habermas, the rational will is the result of the unforced force of the better argument. If an agreement is to be a product of the rational will, then the only permissible force is the "peculiarly unforced force of the better argument” (McCarthy 1989, 308). Habermas hastens to note that the only permissible motive is the cooperative search for truth. In an ideal speech discourse, one can discover and distinguish a rational consensus from a de facto consensus because, according to Habermas, the claim of truth requires a stronger justification than our matter-of fact agreement (McCarthy 1989, 307). According to McCarthy (1989), it requires that we include, as a condition of our agreement, the normative sense of being well grounded. In other words, Habermas is saying that any competent rational judge would come to the same conclusion; that, in the eventuality that anyone should disagree, we could — if only this person would let himself be guided by the force of the better argument-bring him to agree with us (McCarthy 1989, 307-08). The criterion of truth is "not the fact that some consensus has been reached, but rather that at all times and in all places, if only we enter into a discourse, a consensus can be arrived at under conditions which show the consensus to be grounded" (McCarthy 1989, 308). This means that consensus that warrants the truth claim is rationally motivated solely by force of argumentation as opposed to contingent, extraneous factors. This, therefore, is what can be understood as “rational reconstruction” or “quasi-transcendental.”

Kant uses an almost similar approach to formulate his understanding of the rational will. Kant conceptualizes the law as a product of the rational will— “the will of every rational being as a will which makes universal law” (Kant 1785; Paton 2005, 70). Kant is here excluding from any consideration other maxims which are not in unison with this principle. Any other ways of explaining moral obligations by means of other interests would, to all intents and purposes, reject morality altogether. For him, such forms suggest a doctrine of heteronomy, in other words, a will that is constrained by a law based on a reason other than the will itself. This principle is directly connected with the Categorical Imperative, namely that one should "Act only on that maxim through which you can at the same time will that it should become a universal law” (Kant 1785; Paton 2005, 52).

Kant's intention is to remove any effect of inclination. By means of his Categorical Imperative, Kant provides us with a test by which the individual, as a moral agent, may discern what every rational being would will. By the description on rational being he is referring to a being who is free from human sensibilities. Kant calls rational beings intelligible characters who can only will that which every other rational being could will-i.e., duty (Finlayson 1998, 8). This position was criticized by Hegel in his Philosophy of Right (PR§135) and in his lectures on the History of Philosophy. Before Hegel, Lockeans had criticised this Kantian position 
towards morality. Lockeans were in fact the first to criticize Kant's Categorical Imperative as being empty (Beiser 1987, 171). We cannot here diverge into a full discussion of Hegel's critique, but it will suffice to show that Kant, in Hegel's opinion, has contributed nothing to the determination of duty except the form of identity which is, in Hegel's own words, the "law of abstract understanding" (Hegel 1896; Haldane and Simon 1963, 460). In other words, Hegel shows that there is no freedom of choice when it comes to moral actions. For Kant, freedom had to be the result of a pure rational will, while Hegel's freedom points towards the opposite direction. It is a freedom of self-determination and not dependence from external intervention (Taylor 1975, 31-32).

Finlayson (1998) highlights a degree of similarity when he demonstrates how the rational being could draw the same conclusion about a moral action. He says that just students in a logical test would reach the same conclusions, so would Kant's moral agents ultimately concur in their summation. Undoubtedly, at face value, this is dissimilar to what Habermas wants to show in his discourse ethics. Viewed within the light of the Categorical Imperative, Habermas is evidently seeking a different approach. For Habermas the rational being would reach agreement through practical deliberation and intersubjective discourse, and not through the Kantian approach of "unargued for presupposition of practical deliberation" (Finlayson 1989, 8). Discourse ethics provides us with participants in a practical discourse-real beings that are also compelled by other motives - strategic actions. According to Finlayson (1998), the idea behind discourse ethics is to provide the ground whereon distorted interests are corrected and this, therefore, is the pragmatic feature of discourse ethics. In this way, Habermas provides an intersubjective approach to philosophy rather than a traditional monological approach. Habermas can thus be taken to be offering a defence against the charge of idealism and of being indicted, in turn, with the same critique that was brought by Hegel against Kant.

Deeper reflection would show, however, that beneath this dissimilarity there is a measured amount of similarity. The ground provided by Habermas with the aim of correcting distorted interests would suggest that there is, in fact, a slight correspondence between the rational will proposed by Kant and the Habermasian idea that if one wants to arrive at a truth claim, one would have to be rationally motivated. By this latter idea, Habermas means that the only permissible argumentation is one without any form of contingent, extraneous factors (McCarthy 1989, 308). Bearing a similarity to Kantian thought is the fact that Habermas wants the individual to intervene in a cooperative search for truth without, however, an external baggage of interests. While he wants discourse to be ideal, this very characteristic would effectively mean having a discourse that is sterile of any personal perspectives or inclinations, something that is also required from Kant who himself wants the rational being to be free from human sensibilities. McCarthy (1989) pinpoints this form of similarity by saying: "If agreement is to the product of a 'rational will' (Kant), then the only permissible force is the 'peculiarly unforced force of the better argument'." Just to be the Habermasian position, however, it must be noted that this would result in or would be, rather, the cooperative search for truth and not a sole search for truth as in the Kantian perspective. Also, Habermas includes the concept of truth (though pragmatic) which ultimately points "to a form of interaction that is free from all distorting influences" (McCarthy 1989, 308).

Habermas's pragmatic theory of truth should answer the above question and should consequently show that agreement is, above all, actual rather than totally procedural. The pragmatic notion of truth rests with human interests of everyday life and not just with human reason. Truth is founded in experience and not in some a priori knowledge. It is only in discourse that we publicize and confront our own views and the views of others. But then another question must be asked: What is actually pragmatic and how can inter-subjective discourse be exhaustive of all possible intentions and interests? Although it is true that inter-subjectivity plays a 
vital role (because only an actual agreement on human interests can be sufficient enough to generate a universal consensus as opposed to the judgment of what people should want), it remains to be discovered what actuality indeed means and what, by implication, actual agreement really means. One is here constrained to observe that although the Habermasian position places us in a less confined position as compared to the Kantian position of removing any form of desired intention and interest, Habermas still restricts the individual to the confinement of an idealizing proviso - that of subscribing to the better argument. Hence, we can say that although Kant's project is entirely based on procedure and on what is prescribed by rules-doing away, therefore, with any form of self-determination (Taylor 1975, 31) —Habermas's project is not entirely so but it remains, nevertheless, highly influenced from the Kantian style that freedom can only be acquired through some form of procedure.

What we see in section II is an analysis of freedom from the perspective of both Kant and Habermas. At this point, it may be instructive to draw attention to basic similarities that might make one aware that the underlying structure of Habermas's work emulates, to a certain extent, the Kantian procedural style. Yet I am aware that this similarity might convey the feeling that it is somehow a forced similarity. My aim, however, is to find what lies at the root of so much of the criticism waged against Habermas by thinkers such as Finlayson, noting that Hegel's criticism against Kant also applies to Habermas.

\section{Coercive Suspicions}

\subsection{Respect and Redemption-Two Notions for One}

In the Habermasian framework, freedom could partially mean freedom from strategic motivations. This could, however, only be possible through the redemption or vindication of "validity claims" or "rules of discourse" within the context of interaction. The accomplishment of this would, in turn, connect us to a principle of universalizability: Only those norms that are established through the redemption or vindication of validity claims or rules of discourse are permitted. It follows that the norms which are permitted are those which can find general recognition in their domain of application. The principle serves to exclude "all norms whose content and range of validity are particular" (McCarthy 1989, 313). This is to say, therefore, that consensus is achieved through ideal argumentation under the permissible motive of searching for truth. But this could only result if rules of discourse are redeemed and this is very significant in that it demonstrates a similarity between Habermas and Kant. In Habermas's view, in order to gain redemption, one has to deliberately opt for the unforced force of the better argument. This stance is similar to the one adopted by the Kantian agent who autonomously opts to apply moral laws/duties to himself or herself. This, once again, establishes Habermas's notion of communicative ethics in the sphere of a procedural realization of universalizability.

This overview of the common ground shared by these two philosophers can give us an insight into what lies at the core of their shared notions. One can suggest that the core notion of the Kantian morality is the concept of respect (Achtung): Kant's "rational will” is manifested in pure respect for the law. The only way we can say that we are acting morally is by respecting the law- - "only bare law for its own sake, can be the object of reverence and therewith a command” (Kant 1785; Paton 2005, 15). Kant further explains that freedom can only be realized if we respect the law. In the Critique of Practical reason Kant says: "Respect for the moral law is therefore the sole and also the undoubted moral incentive... the moral law determines the will objectively and immediately in the judgment of reason; but freedom, the causality of which is determinable only through 
the law, consists just in this; that it restricts all inclinations, and consequently the esteem of the person himself, to the conditions of compliance with its pure law” (Kant 1788; Gregor 1997, 78).

Habermas uses the word redemption or vindication (eingelöst) to come up with the same suggestion of freedom as advanced in the quote above. Redemption or vindication is used in almost the same manner to mean "a liberation" and this, in effect, is brought about by the application of validity claims and rules of discourse. It is only in this manner that we can say that we are free from any strategic motivations. We can speak of a "rational will"-in the sense that we are freed from any strategic motivations that might otherwise coerce us into actions that violate our autonomy - when we allow the rule of ideal discourse (which embodies the notion of the unforced force of the better argument) to guide us. Kant took the idea of freedom from his notion of respect for the law. Respect for the moral law should free the individual from his own inclinations of feelings and desires, as he takes respect to be the only incentive of every moral action. Therefore, corresponding to the Kantian notion of achtung (to have respect for-achtung haben vor... ) is the Habermasian notion of eingelöst (Eine Regel einlösen-to make use of the rules of discourse).

It can also be observed that Habermas gives a dual meaning to the notion of freedom; if validity claims or rules of discourse are redeemed (freed) in an ideal speech situation, it follows that individuals (as well) are also freed from strategic actions. Although Habermas's freedom has a dual inference, both types give prime importance to "respect for the law" which is, effectively, what results in freedom. For Kant, it is individual freedom. For Habermas, it is social freedom and it is obtained intersubjectively through a discursive medium that would subject itself to the unforced force of the better argument.

Such force would remove any form of inclination and any form of manipulation and it would result in the same form of conclusion. This idea of coming up with the same form of conclusion, through the redemption of validity claims, is similar, to a certain degree, to the Kantian notion of a "maxim" which can be understood, in terms of Kant, as a principle upon which individuals may act. A type of "maxim" referred to by Kant is "objective principle." This principle is one which every rational agent-having full control of the action performed — would necessarily adopt. Similarly, Habermas maintains that if we were to be guided only by such force, we would have a criteria by means of which to judge whether something is true-the criterion of truth is "not the fact that some consensus has been reached, but rather that at all times and in all places, if only we enter into a discourse, a consensus can be arrived at” (McCarthy 1989, 308). In Kant's opinion, only those actions motivated by this sense of duty are to be considered worthy of having moral content. Those actions which are impulsively performed on the spur of the moment, as well as those which are prompted by a degree of self-interest, are rejected for lack of moral content.

Kant refers to a certain grocer who, in response to competition from other shops, decides not to overcharge the unsuspecting customer. In Habermas's eyes the grocer's actions are strategically oriented. He is acting in conformity with duty (Kant 1785; Paton 2005, 10)—for Kant the grocer assents to duty, but he has done so out of fear of competition from other shops and not out of any sense of duty. His actions can be viewed as being strategically oriented - they are not prompted by the motive of duty (Kant 1785; Paton 2005, 10). Similar to Kant's moral duty, vindicating the rules of discourse has had a fundamental role to play in Habermas's "intersubjectivity." The kind of freedom that Habermas seeks is a freedom not from personal inclinations, as in the grocer's case, but a freedom from any forms of strategic action that manipulate individuals from reaching an understanding. If one enters into this form of dialogue, one would be free from the deception of those whose intention it is to manipulate. 


\subsection{Freedom as Coercion}

The talk of strategic motivation, together with the Kantian notion of an autonomous moral subject, raises the question of coercion. It may seem clear to the reader that Habermas, like Kant, is trying to emancipate the individual from any form of coercion. Frankfurt takes coercion to mean the act of getting someone to perform a certain action (thus becoming the victim of coercion) without being morally responsible (Frankfurt 1998, 38-39). A strategic action such as that of persuading people to vote for a corrupt candidate may very well fit into the framework of coercion. People are persuaded (through strategic discourse) to vote for this corrupt candidate. Are they also, however, morally responsible for taking part in the corruption effected? According to the above definition, the answer is "no" because the voters have been misinformed about the true character and intentions of the candidate. Kant's notion of the moral principle seems to solve the problem of coercion by excluding any other consideration of moral maxim except that which results from the categorical imperative. Similarly, rules of discourse should also, according to Habermas, enable us to exclude any form of coercion. Both Kant's categorical imperative and Habermas's rules of discourse (and thus the ideal speech discourse) intend to transform agents into morally responsible agents. The success of this intention could, however, be better tested after a closer consideration of the notion of coercion as analyzed by Frankfurt in Coercion and Moral Responsibility.

Frankfurt insists that coercion requires that the victim of a threat or an offer should have no alternative but to submit. He gives a lot of weight to the importance of understanding coercion in this way as opposed to using the term coercion to simply describe a situation in which the victim's act of submissal is deemed reasonable. Voting for a corrupt candidate is a reasonable act given the fact that persuasion is perfect because it is the result of a number of sophisticated tools — such as advertisements - which employ rhetoric for maximum impact. It can also be the case that the voters have no alternative other than to vote for this corrupt candidate.

Frankfurt would further insist that the fulfilment of the requirement of coercion becomes complete when the threat or offer demands desires or motives that are beyond the victim's ability to control or when, on the other hand, the victim is convinced that this is the case. He also considers the fact that it is a necessary condition of coercion that a person "should have or be convinced that he has no choice but to submit" (Frankfurt 1998, 41). Frankfurt brings in another feature which should further shed more light on the nature of coercion, namely that it must involve a violation of its victim's autonomy: It forces the victim against his or her will so much so that gives half the chance, the said victim would attempt to overcome the threat or offer if he or she possibly could.

Taking this analysis into account makes one wonder what constitutes both the true nature of an autonomous moral character as described by Kant and the validity of communicative action as described by Habermas. Both Kant and Habermas are trying to work out a procedure whereby they may emancipate the individual or the community from deceptive reasoning. Both of them intend to create a morally responsible individual or community. In other words, both of them attempt to try to remove any factor of coercion from moral action. But the success of their intention is questionable when one takes into consideration the manner in which the individual is convinced of something and is led to condition himself or herself that Kant's categorical imperative or Habermas's rules of discourse should create a morally responsible and free individual.

Taking discourse ethics, with the involvement of validity claims, to be the only emancipatory solution from coercion, convincing the individual that there is no other way except to accept the fact that the ideal 
speech discourse is the only solution to freedom from any coercive powers of strategic motivations is, if Frankfurt's notion of coercion is correct, another form of coercion. I would further suggest that this form of coercion is more coercive than strategic motivation. Leading the individual to believe that following the rules of discourse eliminates coercion may effectively put one in a position of no choice thereby violating the victim's autonomy to think.

Undoubtedly, both the Kantian notion of the categorical imperative and the Habermasian notion of an ideal speech discourse, cannot be classified as threats as Frankfurt would have us believe-it is not a matter of pointing a gun at the head of the victim. It can, however, be considered as a kind of offer but it would still be classified as coercion in the Frankfurtian sense. Frankfurt thinks that offers can also be classified as coercive if they violate the victim's autonomy. Habermas offers the community of speakers a framework of thought by means of intersubjective encounters with the genuine intention of eliminating any form of coercion but, in doing so, he may be forcing us to experience a different form of coercion, that of violating the possibility we have to think otherwise. In conclusion, although Kant's agent is given the possibility of being autonomous in the act of choosing to act according to the call of duty and for duty's sake, I do believe that both thinkers are offering a source of freedom which may be questionable as they both offer a freedom that may at times be void of desires, intentions, and interests—a position which Hegel zealously defends.

\section{Works Cited}

Beiser, Frederick. The Fate of Reason. Cambridge: Cambridge University Press, 1987.

Finlayson, James Gordon. "Hegel's Critique of Kant's Moral Theory and Habermas's Discourse Ethics." <http:www.sussex.ac.uk/users/jgf21/research/PDFin.rtf>. 1998.

Frankfurt, Harry Gordon. The Importance of What We Care About. Cambridge: Cambridge University Press, 1998.

Habermas, Jürgen. Theory and Practice. Trans. John Viertel. Boston: Beacon Press, 1973.

---. Communication and Evolution of Society. Boston: Beacon Press, 1979.

---. The Theory of Communicative Action. Vol. 1. Trans. Thomas McCarthy. Cambridge: Polity Press, 1986.

---. Moral Consciousness and Communicative Action. Trans. Christian Lenhardt and S. Weber Nicholsen. Oxford: Basil Blackwell, 1990.

Hegel, Georg Wilhelm Friedrich. Hegel's Philosophy of Mind. Trans. William Wallace. Oxford: Clarendon Press, 1971.

---. "On the Scientific ways of Treating Natural Law, on its Place in Practical Philosophy and its Relation to the Positive Sciences of Right.” Political Writings. Trans. Barry. Nisbit. Cambridge: Cambridge University Press, 1999. 102-180.

---. Political Writings. Trans. Barry. Nisbit. Cambridge: Cambridge University Press, 1999.

---. Hegel's Lectures on The History of Philosophy. Trans. London: Routledge \& Kegan Paul. 1963.

---. Hegel's Philosophy of Right. Trans. Thomas Malcolm Knox. Oxford: Clarendon Press, 1942.

Kant, Immanuel. Groundwork of the Metaphysics of Morals. Trans. Herbert James Paton. London: Routledge, 2005.

---. Critique of Practical Reason. Trans. Mary Gregor. Cambridge: Cambridge University Press, 1997.

Knowles, Dudley. Hegel and the Philosophy of Right. London: Routledge, 2002.

McCarthy, Thomas. The Critical Theory of Jügen Habermas. Cambridge: The MIT Press, 1989.

Rose, David Edward. Hegel's Philosophy of Right. London: Continuum International Publishing Group, 2007.

Taylor, Charles. Hegel. Cambridge: Cambridge University Press, 1975.

Wood, Allan. Hegel's Ethical Thought. Cambridge: Cambridge University Press, 1990.

---. “The Emptiness of the Moral Will.” Monist 72 (1989): 454-83. 